\title{
O EXERCÍCIO ILEGAL DO PODER DE POLÍCIA AO APREENDER VEÍCULO PELA FALTA DE PAGAMENTO DO IPVA
}

THE ILLEGAL EXERCISE OF THE POWER OF POLICE BY SEIZING VEHICLE BY LACK OF PAYMENT OF IPVA

ALLAN MUNHOZ GOMES ${ }^{1}$

ISSUE DOI: $10.21207 / 1983.4225 .478$

\section{RESUMO}

Este artigo busca demonstrar alguns conceitos, princípios e poderes da administração pública, em especial algumas características relativas ao poder de polícia do Estado. Também é de sua finalidade demonstrar alguns princípios constitucionais, bem como definir e caracterizar tributos, com especial atenção a um imposto - IPVA. Discorrendo, na parte final, sobre os abusos e excessos, por parte do Estado na forma de cobrar o referido imposto da sociedade.

Palavras-chave: Administração Pública. Poder de Polícia. Pagamento do IPVA. Fiscalização Tributária.

\section{ABSTRACT}

This article tries to demonstrate some concepts, principles and powers of the public administration, especially some characteristics related to the

\footnotetext{
${ }^{1}$ Estudante de Direito do $10^{\circ}$ semestre da UNOPAR - Universidade Norte do Paraná. Conciliador do Juizado Especial Cível - Comarca de Apucarana - PR.
} 
police power of the State. It is also for its purpose to demonstrate some constitutional principles, as well as to define and characterize taxes, with special attention to a tax - IPVA. Discussing, in the final part, about the abuses and excesses, on the part of the State in the form of collecting the said company tax.

Keywords: Public Administration. Police Power. Payment of IPVA. Tax Inspection.

\section{INTRODUÇÃO}

O presente trabalho objetiva demonstrar os conceitos e poderes da Administração Pública, com foco nas características relativas ao poder de polícia do Estado. Em sequência, apresentar-se-ão as características acerca dos tributos, dando especial atenção ao imposto.

Abordar-se-á em específico, o exercício ilegal do poder de polícia do Estado, ao apreender um veículo pela falta de pagamento de IPVA.

Demonstrando também os equívocos cometidos pelo legislador do Código de Trânsito Brasileiro, ao condicionar a emissão da Certidão de Registro e Licenciamento do Veículo - CRLV - ao pagamento integral do IPVA - Imposto sobre a Propriedade de Veículos Automotores. Visualizando a violação ao princípio tributário do não confisco, bem como a violação do princípio do contraditório e da ampla defesa.

Seguindo por este caminho, mostra-se que o Estado utiliza-se de meios incorretos para cobrar suas dívidas tributárias referentes ao IPVA, desrespeitando princípios constitucionais inerentes a todos os cidadãos de um Estado democrático de direito.

1 DEFINIÇÃO DE ADMINISTRAÇÃO PÚBLICA

A administração pública é a essência da atuação do Direito Administrativo.

Diante das várias definições da doutrina sobre o conceito de Administração Pública, Odete Medauar assevera: "diz-se mesmo que a 
Administração se deixa descrever, mas não se deixa definir, sobretudo ante sua complexidade e o caráter multiforme de suas atuações". ${ }^{2}$

A essência que podemos extrair dos conceitos de alguns doutrinadores é que, em sua maioria, tais conceitos se referem à gestão de bens e interesses, no qual objetivam o bem da sociedade.

À luz de Hely Lopes Meirelles, a administração pública "é a gestão de bens e interesses qualificados da comunidade no âmbito federal, estadual ou municipal, segundo os preceitos do Direito e da Moral, visando o bem comum". ${ }^{3}$

Ainda segundo o mesmo autor:

Os fins da administração pública resumem-se num único objetivo: o bem comum da comunidade administrada. Toda atividade do administrador público deve ser orientada para esse objetivo. Se dele o administrador se afasta ou desvia, trai o mandato de que está investido, porque a comunidade não institui a Administração senão como meio de atingir o bem estar social. Ilícito e imoral está todo ato administrativo que não for praticado no interesse da coletividade. ${ }^{4}$

Desta maneira, nota-se que a Administração Pública deve nortear-se visando o bem comum da sociedade, pautando a atividade do administrador, para que ela não se afaste ou se desvie, evitando dessa maneira que tais atos se tornem ilícitos ou imorais.

\section{PODERES DA ADMINISTRAÇÃO PÚBLICA}

Para que a administração pública possa exercer suas funções, ela necessita de poderes, que o ordenamento jurídico lhe confere, fazendo

\footnotetext{
2 MEDAUAR, Odete. Direito administrativo moderno. 18 ed. rev. e atual. São Paulo: Revista dos Tribunais, 2014. p. 59.

3 MEIRELLES, Hely Lopes. Direito administrativo brasileiro. 37 ed. São Paulo: Malheiros Editores, 2011. p. 85.

${ }^{4}$ Ibidem.
} 
com que, desta maneira, o interesse público se sobreponha ao interesse privado, a vontade da lei face à vontade individual.

Segundo Maria Sylvia Zanella Di Pietro:

Embora o vocábulo poder dê a impressão de que se trata de faculdade da Administração, na realidade trata-se de poder-dever, já que reconhecido ao poder público para que exerça em benefício da coletividade; os poderes são, pois, irrenunciáveis. (Grifo do autor). ${ }^{5}$

Porém, tais poderes não podem ser exercidos de maneira exacerbada, descontrolada, sem se observar nenhum critério. Devem-se observar os limites impostos pela lei, bem como os princípios jurídicos e constitucionais.

Entre os poderes normativos, disciplinares, hierárquicos e o poder de polícia, têm-se o poder discricionário e o vinculado, não sendo estes dois últimos considerados por parte da doutrina como poderes autônomos, pois são considerados atributos de outros poderes, ou também como competência da Administração Pública.

\subsection{PODER DE POLÍCIA}

A Administração Pública utiliza-se do poder de polícia para condicionar os direitos de cada cidadão, buscando o bem-estar coletivo, ou seja, é um meio pelo qual se procura assegurar os direitos individuais que possam ser ameaçados através de um exercício ilimitado de cada cidadão.

Maria Sylvia Zanella Di Pietro nos esclarece acerca do fundamento do poder polícia: “o fundamento do poder de polícia é o princípio da predominância do interesse público sobre o particular, que dá à Administração posição de supremacia sobre os administrados". ${ }^{6}$

5 DI PIETRO, Maria Sylvia Zanella. Direito administrativo. 26 ed. São Paulo: Atlas, 2012. p. 90.

${ }^{6}$ Ibidem. p. 85. 
Nesse mesmo sentido, José dos Santos Carvalho Filho assevera que o poder de polícia é "a prerrogativa de direito público que, calcada na lei, autoriza a Administração Pública a restringir o uso e gozo da liberdade e da propriedade em favor do interesse da coletividade". ${ }^{7}$

Dessa maneira, observa-se que o poder de polícia é de extrema importância para que se mantenha a ordem social, porém, deve limitar-se rigorosamente ao ordenamento jurídico, bem como aos princípios, para que se não cometam abusos por parte do Estado sobre o particular.

Acerca deste abuso Maria Sylvia Zanella Di Pietro transcreve: "a autoridade que se afastar da finalidade pública incidirá em desvio de poder e acarretará a nulidade do ato com todas as consequências nas esferas civil, penal e administrativa". (Grifo do autor). ${ }^{8}$

Desta feita, o poder de polícia torna-se inválido quando é utilizado de maneira desproporcional ou excessiva, havendo outros meios de se atingir o mesmo objetivo.

Alguns atributos devem ser observados acerca do poder de polícia, quais sejam, a discricionariedade, autoexecutoriedade e a coercibilidade, e mais recentemente adicionada a essa lista, está a indelegabilidade.

Em grande parte das medidas de polícia, encontra-se a discricionariedade, porém, a legislação certas vezes abre espaço para que haja uma liberdade na maneira de se analisar alguns elementos, como o motivo ou o objeto. Com isso, o poder de polícia torna-se discricionário, pois a Administração é quem decide os meios adequados para agir, dentre as normas previstas na legislação.

Não raramente, há a vinculação, quando o legislador esgota todas as hipóteses de ação, o que faz com que o agente público não tenha espaço para decidir desta ou daquela forma; ele simplesmente analisa os requisitos, se preenchidos, deve agir como está previsto em lei.

Em relação à autoexecutoriedade, a administração, através de seus próprios meios, executa suas decisões sem que seja necessário recorrer ao Judiciário.

Nesse escopo, Diógenes Gasparini leciona:

\footnotetext{
${ }^{7}$ CARVAlHO FILHO, José dos Santos. Manual de direito administrativo. 25 ed. São Paulo: Atlas, 2012. p. 73.

${ }^{8}$ DI PIETRO, Maria Sylvia Zanella. Direito administrativo. 26 ed. São Paulo: Atlas, 2012. p. 128.
} 
A Administração Pública pode promover, por seus próprios meios, humanos e materiais, a submissão do administrado às determinações editadas, para vê-lo conformado à legislação a que deve obediência, sem necessidade de recorrer a qualquer outro poder. ${ }^{9}$

Não se vislumbra esse atributo em todos os atos de polícia, pois para que a Administração utilize-se dessa faculdade, é necessário que haja lei expressa autorizando. Porém, em se tratando de situações urgentes e não regulamentadas, a Administração Pública deve recorrer ao Judiciário para que se valha o interesse público.

Celso Antônio Bandeira de Mello assevera a respeito das situações em que o administrado recorre ao Judiciário para reaver seu direito em face da Administração Pública:

É óbvio, todavia, que em todas as hipóteses os particulares podem sempre recorrer ao Poder Judiciário para sustar as providências administrativas que tenham fundado receio de vir a sofrer em desconformidade com a lei ou para obter as reparações devidas quando, da atuação ilegal da Administração, venham sofrer danos causados a pretexto do exercício do poder de polícia. ${ }^{10}$

Dessa forma, o fato da Administração Pública fazer valer o seu poder de polícia, não pode ultrapassar os limites legais, observando sempre o interesse público.

Destarte, Diógenes Gasparini aduz: "o uso do poder só se legitima quando normal, isto é, quando aplicado para a consecução de interesses públicos e na medida em que for necessário para tais interesses". ${ }^{11}$

O abuso do poder é caracterizado quando um ato administrativo, legal ou ilegal é praticado de forma irregular. Gasparini complementa:

\footnotetext{
${ }^{9}$ GASPARINI, Diógenes. Direito administrativo. 16 ed. São Paulo: Saraiva, 2011. p. 186.

${ }^{10}$ MELLO, Celso Antônio Bandeira de. Curso de direito administrativo. 26 ed. São Paulo: Malheiros, 2009. p. 835

11 GASPARINI, Diógenes. Direito administrativo. 16 ed. São Paulo: Saraiva, 2011. p. 194.
} 
"o abuso de poder é toda ação que torna irregular a execução do ato administrativo, legal ou ilegal". ${ }^{12}$

Um ato administrativo perfeitamente legal, se executado por um agente público de maneira ilegal ou viciada, pode vir a tornar-se um ato ilegal. Nesse sentido, Fábio Bellote Gomes preceitua: "assim, ocorre o abuso de poder ou abuso de autoridade quando o agente público, embora competente, ao executar o ato administrativo (que em si pode ser legal ou ilegal), excede os limites de suas atribuições legais na prática do ato". ${ }^{13}$

E finaliza Fábio Bellote Gomes: "o abuso do poder ou abuso de autoridade relaciona-se exclusivamente aos aspectos materiais do ato administrativo". ${ }^{14}$

Nesta mesma senda, define-se o excesso de poder como sendo aquele em que o agente público ultrapassa os limites de suas atribuições.

Hely Lopes Meirelles leciona acerca deste tema:

O excesso de poder ocorre quando a autoridade competente para praticar o ato, vai além do permitido e exorbita o uso de suas faculdades administrativas. Excede, portanto, sua competência legal e, com isso, invalida o ato, porque ninguém pode agir em nome da administração fora do que a lei lhe permite. ${ }^{15}$

Assim, o ato administrativo cometido com excesso, não é totalmente ilegal, uma vez que parte dele foi praticada conforme definido em lei. Desse modo, o ato é válido naquilo em que não excedeu os limites legais, exceto o próprio excesso, salvo se, em decorrência desse excesso, viciar todo o conteúdo do ato. À vista disso, o excesso de um ato pode ser convalidado, todavia, desde que não acarrete nenhum prejuízo a terceiros.

12 GASPARINI, Diógenes. Direito administrativo. 16 ed. São Paulo: Saraiva, 2011. p. 200.

13 GOMES, Fábio Bellote. Elementos de direito administrativo. 2 ed. São Paulo: Saraiva, 2012. p. 89.

${ }^{14}$ Ibidem. p. 89.

15 MEIRELLES, Hely Lopes. Direito administrativo brasileiro. 37 ed. São Paulo: Malheiros Editores, 2011. p. 114. 
Seguindo adiante, o desvio de finalidade caracteriza-se quando o agente público busca um fim diverso ao interesse da sociedade ou da lei.

Hely Lopes Meirelles perfilha: "o desvio de finalidade ou de poder verifica-se quando a autoridade, embora atuando nos limites de sua competência, pratica o ato por motivos ou com fins diversos dos objetivados pela lei ou exigidos pelo interesse público". ${ }^{16}$

Comete assim, o agente público, uma violação moral, visto que se utiliza da lei, aparato legal, de maneira divergente da finalidade pretendida pelo legislador. Excluindo os interesses públicos em virtude de interesses próprios ou alheios. Ocorrendo o desvio de finalidade, o ato se torna nulo, impassível de convalidação.

Gasparini complementa: "no desvio de finalidade o ato administrativo é ilegal por inteiro. Não há como aproveitá-lo. É ato nulo e, como tal, é assim entendido pela doutrina e pela jurisprudência". ${ }^{17}$

\section{DIREITO AO DEVIDO PROCESSO LEGAL}

A Constituição Federal dispõe acerca do devido processo legal em seu artigo $5^{\circ}$, nos incisos LIV e LV, in verbis:

Art. $5^{\circ}$. Todos são iguais perante a lei, sem distinção de qualquer natureza, garantindo-se aos brasileiros e aos estrangeiros residentes no País a inviolabilidade do direito à vida, à liberdade, à igualdade, à segurança e à propriedade, nos termos seguintes:

[...] LIV - ninguém será privado da liberdade ou de seus bens sem o devido processo legal;

LV - aos litigantes, em processo judicial ou administrativo, e aos acusados em geral são assegurados o contraditório e a ampla defesa, com os meios e recursos a ela inerentes;

\footnotetext{
16 MEIRELlES, Hely Lopes. Direito administrativo brasileiro. 37 ed. São Paulo: Malheiros Editores, 2011. p. 114.

17 GASPARINI, Diógenes. Direito administrativo. 16 ed. São Paulo: Saraiva, 2011. p. 197.
} 
Dessa forma, tem-se que o devido processo legal garante ao cidadão a paridade de armas, bem como a inafastabilidade do controle jurisdicional, garantindo ainda, em termos de ampla defesa, a defesa técnica e autodefesa, e também, o duplo grau de jurisdição e proibição de provas ilícitas.

Nesse sentido, o devido processo legal, como garantia constitucional, deve ser respeitado por todas as normas infraconstitucionais, sob pena de inconstitucionalidade da norma ou decisão que ferir tal garantia.

Contudo, o artigo 230, inciso V do Código de Trânsito Brasileiro prevê que:

Art. 230. Conduzir veículo:

[...] $\mathrm{V}$ - que não esteja registrado e devidamente licenciado;

[...] Penalidade - multa e apreensão do veículo;

De acordo com tal dispositivo, fica claro que se um cidadão é parado em uma blitz de trânsito e seu veículo não se encontra devidamente registrado e licenciado, ele receberá uma multa e ainda terá seu veículo apreendido.

É dever de todo contribuinte estar com os pagamentos dos seus tributos em dia, bem como com sua CRLV totalmente regularizada. Entretanto, não justifica a apreensão do veículo que não esteja com o IPVA em dia, visto que, o administrado estará sofrendo uma restrição ao seu direito de propriedade sem que haja o devido processo legal.

Silva:

Nesse seguimento é o entendimento de Paulo Roberto Coimbra

Ora, havendo procedimentos legalmente previstos para a devida cobrança de crédito tributário, que, a propósito, possui contundentes garantias e privilégios (art. 183 a 193, do CTN), é vedada à Administração Pública a utilização de outros mecanismos neste mister. De fato, se o Estado já dispõe de um meio legal e idôneo para a exigência de suas dívidas, que é a ação de execução fiscal, aliada ao protesto da dívida ativa, não lhe é lícito utilizar-se de outros expedientes como forma de 
coação dos contribuintes/proprietários para a satisfação seus próprios arrecadatórios. ${ }^{18}$

Dessa maneira, quando a Administração Pública age da forma definida no CTB, ela está infringindo o que está disposto no art. $5^{\circ}$, inciso LIV da CF, uma vez que a norma contida na Constituição Federal é superior ao que está disposto no CTB (norma infraconstitucional), o que torna a matéria do referido artigo do CTB inconstitucional, visto que, ao apreender o veículo pelo não pagamento do IPVA, ocorre uma ilegalidade.

É mister demonstrar que a apreensão do veículo seria corretamente efetuada somente após um processo administrativo ou uma execução fiscal, ou seja, os meios corretos e dispostos legalmente para se cobrar um tributo. Dessa forma, o contribuinte poderia se manifestar, sendo observados o contraditório e a ampla defesa.

O Estado comete um excesso do poder de polícia ao apreender um veículo ilegalmente, restringindo o direito à propriedade sem o devido processo legal e afrontando diretamente a Constituição Federal.

\section{$4 \quad$ PRINCÍPIO DO NÃO CONFISCO E O DIREITO DE PROPRIEDADE}

O princípio da vedação ao confisco está intimamente ligado ao direito de propriedade. Neste giro, Eduardo de Moraes Sabbag aduz:

[...] o povo outorga ao legislador o poder de representação, esperando que este se exerça, na via do tributo, por meio de norma que não vilipendie seu patrimônio.

Com efeito, o princípio que veda a confiscatoriedade "otimiza o direito de propriedade", reforçando-o na

18 SABBAG, Eduardo de Moraes. Manual de direito tributário. 6 ed. São Paulo: Saraiva, 2014. p. 236. 
essência, uma vez derivável dos direitos fundamentais do contribuinte. (Grifo do autor). ${ }^{19}$

Nessa esteira, Luciano Amaro perfilha:

Desde que a tributação se faça nos limites autorizados pela Constituição, a transferência de riqueza do contribuinte para o Estado é legitima e não confiscatória. Portanto, não se quer, com a vedação ao confisco, outorgar à propriedade uma proteção absoluta contra a incidência do tributo, o que anularia totalmente o poder de tributar. $\mathrm{O}$ que se objetiva é evitar que, por meio do tributo, o Estado anule a riqueza privada. ${ }^{20}$

Importante frisar que o que se deseja não é o abuso por parte dos cidadãos ao poder de tributar, ou desrespeitar os poderes inerentes ao Estado, mas sim que o Estado, através de tributo e do seu poder de polícia, não se utilizar destes como meio de agredir o direito à propriedade, usurpando do cidadão qualquer meio e chance de defesa e desrespeitando princípios constitucionais basilares de um estado de direito.

O princípio tratado neste tópico está inserido no texto Constitucional em seu artigo 150, inciso IV, ipsis verbis:

Art. 150. Sem prejuízo de outras garantias asseguradas ao contribuinte, é vedado à União, aos Estados, ao Distrito Federal e aos Municípios:

[...] IV - utilizar tributo com efeito de confisco;

Nesta senda, encontra-se amparo legal disposto explicitamente na Constituição Federal de 1988, o que acarreta menos interpretações divergentes atinentes a este tema.

Tamanha importância é a vedação ao confisco, que ele vem sendo tratado desde a Constituição de 1934, mesmo que recebendo algu-

19 SILVA, Paulo Roberto Coimbra. IPVA: Imposto sobre a propriedade de veículos automotores. São Paulo: Quartier Latin, 2011. p. 179.

${ }^{20}$ AMARO, Luciano. Direito tributário brasileiro. 14 ed. São Paulo: Saraiva, 2008. p. 144. 
mas alterações. O legislador se preocupou em tratar do tema, para que assim, evitasse o abuso de poder por parte do Estado sobre o cidadão, tornando a relação mais equânime e ponderada, entre o cidadão e o Estado.

\section{DEFINIÇÃO DE TRIBUTOS}

$\mathrm{O}$ artigo $3^{\circ}$ do Código Tributário Nacional define tributo: "tributo é toda prestação pecuniária compulsória, em moeda ou cujo valor nela se possa exprimir, que não constitua sanção de ato ilícito, instituída em lei e cobrada mediante atividade administrativa plenamente vinculada”. De acordo com a teoria pentapartida, têm-se como exemplo de tributos os impostos, as taxas e contribuições de melhoria, contribuições sociais e empréstimos compulsórios.

Nesse diapasão, Aliomar Baleeiro perfilha sobre tributo: “o CTN adotou a teoria segundo a qual tributos se caracterizam pelo caráter compulsório e, para distingui-los das multas e penalidades, inseriu a cláusula "que não constitua sanção de ato ilícito". ${ }^{21}$

Nesta senda, Paulo de Barros Carvalho preceitua:

[...] uma vez que os acontecimentos ilícitos vêm sempre atrelados a uma providência sancionatória e, fixando o caráter ilícito do evento, separa-se com nitidez, a relação jurídica do tributo da relação jurídica atinente às penalidades exigidas pelo descumprimento dos deveres tributários. Como são idênticos aos vínculos, isoladamente observados, é pela associação ao fato que lhe deu origem que vamos conhecer a índole da relação. ${ }^{22}$

A compulsoriedade não dá ao cidadão (sujeito passivo da obrigação) a opção de escolher entre o pagamento ou não pagamento do tributo, já que, enquadrado no fato gerador, não lhe resta alternativa a não

\footnotetext{
${ }^{21}$ BALEEIRO, Aliomar. Direito tributário brasileiro. Atualização de Misabel Abreu Machado Derzi. 12 ed. Rio de Janeiro: Forense, 2013. p. 30.

${ }^{22}$ CARVAlHO, Paulo de Barros. Curso de direito tributário. 23. ed. São Paulo: Saraiva, 2011. p. 58.
} 
ser pagar. Não pagando, incorre nas sanções previstas na legislação na qual o Estado (sujeito ativo da obrigação) deve-se utilizar dos meios legais necessários para recolher tal valor.

Sérgio Pinto Martins assevera: "compulsório não quer dizer obrigatório, mas significa que independe da vontade da pessoa de contribuir. A pessoa não paga o tributo porque quer ou gosta. Se isso ocorresse, não pagaria o tributo". ${ }^{23}$

\section{$5.1 \quad$ IMPOSTO}

O imposto é uma espécie de tributo, todavia, existem, além do imposto, as taxas, as contribuições de melhoria, contribuições sociais e empréstimos compulsórios como outras espécies de tributos. Porém, apenas três encontram-se previstas no artigo $5^{\circ}$ do Código Tributário Nacional. As outras duas espécies encontram-se previstas nos artigos 148 e 149 da Constituição Federal de 1988, de forma que somente a União se mostra competente para instituir estas duas últimas espécies.

Na trilha da teoria tripartida, Sacha Calmon Navarro Coêlho enfatiza que "tributo é categoria genérica que se reparte em espécies: impostos, taxas e contribuições de melhoria". ${ }^{24}$

Atualmente, predomina na doutrina a teoria pentapartida (pentapartite ou quinquipartida), no qual o gênero tributo é divido em cinco espécies, conforme mencionado no início deste tópico.

O imposto ainda possui uma característica peculiar que o difere dos outros tributos. Essa característica está prevista no artigo 16 do CTN, sendo: "imposto é o tributo cuja obrigação tem por fato gerador uma situação independente de qualquer atividade estatal específica, relativa ao contribuinte".

Nesse passo, Eduardo de Moraes Sabbag também define imposto: "imposto é tributo cuja obrigação tem por fato gerador uma situação

\footnotetext{
${ }^{23}$ MARTINS, Sérgio Pinto. Manual de direito tributário. 11. ed. São Paulo: Atlas, 2012. p. 79.

${ }^{24}$ COÊLHO, Sacha Calmon Navarro. Comentários à Constituição de 1988. 7 ed. Rio de Janeiro: Forense, 1998. p. 2.
} 
independente de qualquer atividade estatal específica, relativa à vida do contribuinte, à sua atividade ou a seu patrimônio". ${ }^{25}$

Dessa forma, o fato gerador do imposto não necessita de uma atividade do Estado, ou seja, o Estado não precisa prestar uma atividade para que se possa instituir o imposto, o que torna o imposto um tributo não vinculado, diferentemente das taxas e contribuições.

$\mathrm{O}$ tributo não vinculado quer dizer que, pagando determinado imposto, o dinheiro arrecadado com ele pode ser utilizado de maneira generalizada, ou seja, o fruto de sua arrecadação pode ser utilizado para outros fins, como por exemplo, o dinheiro arrecadado com IPVA, não precisa ser necessariamente destinado à manutenção de estradas e ruas, pode ser destinado à educação, saúde, etc.

Já as outras espécies de tributos são vinculadas, pois o fruto de sua arrecadação deve ser destinado a um serviço determinado. Tem-se como exemplo a contribuição de melhoria, na qual é devido pelos moradores de determinada região quando um ente federal realiza uma obra pública e ocorre a valorização imobiliária.

Desta feita, observa-se que o imposto é um importante meio de arrecadação do Estado para manter a máquina estatal, posto que seu objeto é uma situação genérica, fazendo com que qualquer contribuinte fique sujeito à sua prestação, desde que se preencham os requisitos estabelecidos em lei.

\subsection{IMPOSTO SOBRE A PROPRIEDADE DE VEÍCULOS AUTOMOTORES - IPVA}

O IPVA é caracterizado como um imposto incidente sobre o patrimônio, neste caso, sobre a propriedade de veículos automotores, seja automóvel, motocicleta, caminhão, etc. O artigo 155, inciso III da Constituição Federal dispõe sobre este imposto.

Segundo Eduardo de Moraes Sabbag: “o IPVA é um imposto estadual, com disciplinamento na Constituição Federal, no comando inserto no inciso III do art. $155^{\prime 26}$, e continua o autor:

${ }^{25}$ SABBAG, Eduardo de Moraes. Manual de direito tributário. 6 ed. São Paulo: Saraiva, 2014. p. 416. 
Por outro lado, não há menção a tal tributo no CTN, uma vez que seu nascimento data de 1985, com a promulgação da Emenda n. 27/85 à Constituição Federal de 1967, vindo a lume substituir a antiga “TRU” - Taxa Rodoviária Única. (Grifo do autor). ${ }^{27}$

O sujeito passivo é o proprietário de veículo automotor (pessoa física ou jurídica), sendo o fato gerador a propriedade do veículo, e não incidindo somente perante a posse ou uso. Este imposto começa a ser devido a partir do momento da compra, ou seja, apenas quando o destinatário final adquire o produto.

O IPVA é cobrado anualmente e possui como base de cálculo o valor venal do veículo, isto é, seu valor de mercado.

Diferentemente dos outros impostos, o IPVA não possui uma sistemática normativa de âmbito nacional, sendo cada Estado-Membro da Federação responsável por legislar, através de leis ordinárias, a instituição e regulamentação deste imposto. Dessa maneira, o referido imposto pode sofrer alterações a depender da legislação estadual que se analise.

Em regra, o lançamento do IPVA é feito de ofício. A repartição de sua receita é feita por rateio, no qual, $50 \%$ ficam para o Estado responsável pela cobrança e os outros $50 \%$ vão para o Município onde o veículo está licenciado.

No que concerne à fiscalização do IPVA, foi permitido à Fazenda Pública que se valesse de convênios com Departamentos de Trânsito para que conseguisse atuar de maneira eficaz. Nesse sentido, Gladston Mamede aduz:

Quando são veículos automotores cuja circulação está submetida à fiscalização de órgãos públicos específicos, como os Departamentos de Trânsito DETRAN [...] a colaboração entre esses e a Fazenda pode produzir excelentes resultados. [...] os Departamentos Estaduais de Trânsito, através dos certificados de registro e licenciamento de veículo, que somente são emitidos com o recolhimento do

${ }^{26}$ SABBAG, Eduardo de Moraes. Manual de direito tributário. 6 ed. São Paulo: Saraiva, 2014. p. 1124.

${ }^{27}$ Ibidem. 
tributo, cumprem um papel facilitador incontestável da fiscalização tributária. O legislador estadual bem sabe dessas facilidades e procura beneficiar-se delas, prevendo, não raro, convênios com órgãos de registro. ${ }^{28}$

Tal convênio se demonstra o meio mais eficaz para que o Estado consiga fiscalizar. É um meio legítimo, porém, desde que seja para multar e apreender veículos que trafeguem sem o CRLV, e não para cobrar, mesmo que indiretamente um imposto - o IPVA.

\subsection{CERTIFICADO DE REGISTRO E LICENCIAMENTO DE VEÍCULOS - CRLV}

O CRLV é um documento de porte obrigatório, exceto, quando no momento da fiscalização, for possível o acesso ao sistema informatizado que seja capaz de verificar se o veículo encontra-se devidamente licenciado. A finalidade deste documento é de atestar que o veículo possui condições de segurança para estar em circulação. $\mathrm{O}$ artigo 230, inciso V, do Código de Trânsito Brasileiro prevê multa e apreensão do veículo, caso não esteja registrado e devidamente licenciado.

O artigo 131, $\$ 2^{\circ}$ do CTB dispõe:

Art. 131. O Certificado de Licenciamento Anual será expedido ao veículo licenciado, vinculado ao Certificado de Registro, no modelo e especificações estabelecidos pelo CONTRAN.

[...] $\$ 2^{\circ} \quad \mathrm{O}$ veículo somente será considerado licenciado estando quitados os débitos relativos a tributos, encargos e multas de trânsito e ambientais, vinculadas ao veículo, independentemente da responsabilidade pelas infrações cometidas.

Portanto, mesmo que o contribuinte não possua débitos relativos a seu veículo, ou já tenha efetuado o pagamento de tais débitos, sem o

\footnotetext{
${ }^{28}$ MAMEDE, Gladston. IPVA: imposto sobre a propriedade de veículos automotores. São Paulo: Revista dos Tribunais, 2002. p. 158.
} 
pagamento do IPVA, até o seu vencimento, não será expedido seu CRLV, o que acarretará em multa e apreensão do veículo, visto que sua expedição está condicionada ao pagamento do IPVA. Deste modo, o veículo será apreendido indiretamente por falta de pagamento do IPVA.

Nesse compasso, Paulo Roberto Coimbra Silva preceitua:

[...] uma vez superada a inspeção veicular prevista nos artigos 103, 104 e seguintes do CTB, sem ressalvas, deve o agente responsável deferir o licenciamento anual, que deve ser consignado e atestado pelo respectivo certificado (CRLV), independente da comprovação de quitação dos tributos atinentes à propriedade e utilização do veículo, ou mesmo que estes constem em aberto dos arquivos da fazenda pública. Assim deve ser exercido o poder de polícia da Administração Pública, tal qual definido no art. 178 do CTN, criado para a tutela do interesse da coletividade, sem desvirtuar-se de seus elevados fins para atender a propósitos ou necessidades arrecadatórias, mormente ao se considerar serem o registro e o licenciamento anual indispensáveis à regular circulação do veículo pelas vias públicas, sob pena de remoção. É igualmente abusiva se revela a recusa em se restituir o veículo pelo não pagamento do IPVA, ou condicioná-lo à quitação do crédito tributário exigido. ${ }^{29}$

Com base nisso, nota-se que o IPVA é um imposto cobrado sobre a propriedade de veículo automotor, enquanto o CRLV é um documento expedido para comprovar que o veículo possui condições para circular em segurança. Desta feita, vislumbra-se que o legislador deu uma finalidade diversa ao condicionar a emissão da CRLV ao pagamento do IPVA, utilizando-se deste meio para arrecadar o imposto, cuja finalidade é comprovar que o veículo possui condições de trafegar em segurança.

${ }^{29}$ SILVA, Paulo Roberto Coimbra. IPVA: Imposto sobre a propriedade de veículos automotores. São Paulo: Quartier Latin, 2011. p. 182. 


\section{6}

\section{O EXERCÍCIO ILEGAL DO PODER DE POLÍCIA AO APREENDER VEÍCULO PELA FALTA DE PAGAMENTO DO IPVA}

O pagamento de um tributo é dever do contribuinte, uma vez que, enquadrado nas hipóteses do fato gerador, ele é obrigado a pagar, sob pena de responsabilidade.

Conforme já mencionado anteriormente, os tributos são uma importante - senão a mais importante - fonte de receita para que o Estado se sustente e possa cumprir com seus objetivos transcritos na Constituição.

José Casalta Nabais preceitua sobre a importância dos tributos para o Estado:

[...] um Estado, para cumprir suas tarefas, tem de socorrer-se de recursos ou meios a exigir dos seus cidadãos, constituindo justamente os impostos esses meios ou instrumentos de realização de tarefas estaduais. Por isso, a tributação não constitui, em si mesma, um objetivo (isto é, um objetivo originário ou primário) do estado, mas sim o meio que possibilita a este cumprir os seus objetivos (originários ou primários), atualmente consubstanciados em tarefas de estado de direito e tarefas de estado social, ou sejam, em tarefas do estado de direito social. ${ }^{30}$

Os tributos devem ser instituídos de maneira equânime e justa, bem como também deve ser justa sua cobrança.

Nesse sentido, Reginaldo de França leciona: "o imposto deve ser justo, concebido segundo os princípios da legalidade e da capacidade contributiva, dentre outros que emanam da Constituição Federal". ${ }^{31}$

\footnotetext{
${ }^{30}$ NABAIS, José Casalta. O dever fundamental de pagar impostos. Contributo para a compreensão constitucional do estado fiscal contemporâneo. Coimbra: Almedina, 1998. p. 186.

31 FRANÇA, Reginaldo de. Fiscalização tributária: prerrogativas e limites. 2 ed. Curitiba: Juruá, 2012. p. 156.
} 
Com isso, o Estado não pode exercer sua fiscalização sem obedecer a regras ou de maneira abusiva; ele deve respeitar os preceitos legais, bem como os princípios constitucionais.

Uma vez devido o tributo, ele se torna parte do patrimônio do Estado, tornando patrimônio público, não podendo o Estado deixar de cobrá-lo, em razão do princípio da inalienabilidade do patrimônio público. Porém o Estado não pode ser injusto na maneira de cobrar tal tributo. O Estado deve valer-se de suas prerrogativas, contudo, respeitando seus limites constitucionalmente delineados.

Nesse giro é o entendimento de Deonísio Koch:

Ao mesmo tempo em que o Estado é dotado de poderes para cobrar tributos para seu financiamento, sendo legítimo por lei a apropriar-se de parte das riquezas dos administrados, o Direito Tributário lhe impõe limites em sua competência tributária, não permitindo que os governos ou autoridades tributantes exercitem suas ganancias arrecadatórias, suprindo o tesouro de recursos abundantes par garantir uma administração pomposa, com o exaurimento das riquezas da população. ${ }^{32}$

Contudo, alguns Estados-membros valem-se do seu poder de polícia para cobrarem coercitivamente esse imposto, sendo que, a maneira adequada para a cobrança seria a execução fiscal, na qual o polo passivo (cidadão/administrado) possui a chance de se defender, apresentar o contraditório, sendo resguardado o direito à ampla defesa, bem como, dessa maneira, sendo respeitado o princípio do não confisco. Pois, da maneira como é feita a apreensão do veículo pela falta de pagamento do IPVA, seria o mesmo que expulsar um cidadão de sua casa por não ter pagado seu IPTU.

Nesse sentido, Ana Flávia Messa leciona:

A fiscalização tributária exige a existência de um processo adequado, com observância do contraditório, da ampla defesa e igualdade

$\mathrm{KOCH}$, Deonísio. Processo administrativo tributário e lançamento. Florianópolis: Editores, 2012. p. 295. 
processual, de forma a repelir a onipotência e arbitrariedade. Dessa forma, é essencial que o destinatário da Fiscalização tenha a possibilidade de ser ouvido, oportunidade para produzir provas e razões, ciência da fiscalização e utilização de meios impugnativos. ${ }^{33}$

Ou seja, o Estado não pode privar o contribuinte de se defender, mesmo que administrativamente. $O$ contribuinte não pode ser privado de seu patrimônio, apreendido de maneira excessiva, sem que possa apresentar contraditório e sem direito à ampla defesa.

É dever de o Estado identificar e fiscalizar os contribuintes que estão em débito, contudo, ele não pode apreender e manter o veículo em sua posse até que o contribuinte pague o imposto, sem que ao menos tenha havido o devido processo legal. Isso caracteriza, por parte do Estado, uma execução indireta, promovida pela Administração Pública, sem haver o acionamento do Poder Judiciário, o que viola nossa Constituição Federal.

Corroborando tal entendimento, Gladston Mamede aduz:

Questionável, portanto, a disposição, na medida em que revela a intenção do legislador de forçar o recolhimento do imposto por vias outras que não as próprias e permitidas. Vale dizer, busca desaforar a relação tributária do campo obrigacional, onde não é lícito ao credor mais do que exigir a satisfação do crédito (com seus acessórios legais), levando-a para outros campos, onde o cerceamento de direitos constitucionalmente garantidos (como a propriedade e a locomoção) criaram danos que forçariam o contribuinte ao recolhimento. ${ }^{34}$

MESSA, Ana Flávia. Limites principiológicos da fiscalização tributária. Revista Tributária e de Finanças Públicas. São Paulo, ano 16. n. 82 set-out 2008, Revista dos Tribunais. p. 41.

MAMEDE, Gladston. IPVA: imposto sobre a propriedade de veículos automotores. São Paulo: Revista dos Tribunais, 2002. p. 165. 
Desta feita, a Administração Pública, para se valer do direito de cobrar o imposto, deve observar os meios legais, a exemplo da execução fiscal, criada justamente para essa finalidade.

Dito isso, considera-se que a Administração Pública deve, por si só, encontrar meios eficientes e eficazes para constituir seu crédito tributário dos cidadãos inadimplentes, e não utilizar-se de meios excessivos e coercitivos, desrespeitando princípios constitucionais e abusando do poder de polícia do Estado, para se valer de um crédito tributário que pode ser cobrado de outras maneiras.

Considera-se também um abuso, por parte do legislador, condicionar a emissão da CRLV, ao pagamento do IPVA. Visto que o IPVA incide sobre a propriedade do bem, enquanto o CRLV incide sobre as condições do veículo para circular em segurança.

\section{CONSIDERAÇÕES FINAIS}

Ao longo dos anos, a sociedade foi se desenvolvendo e com esse desenvolvimento vieram também leis e suas adaptações, sempre se observando princípios e valores que possam proteger a pessoa humana e os cidadãos.

O Estado se utiliza destas leis para organizar a sociedade, para que ela possa ser mais justa possível, mesmo que em certas situações possam-se observar alguns abusos e arbitrariedades por parte do Estado.

Como uma maneira de regular melhor a relação entre Estado e a sociedade, existe a Administração Pública, dotada de poderes conferidos pelo Estado, para que possa exercer suas funções. Para que o Estado mantenha seu funcionamento, ele arrecada tributos da sociedade, onde a princípio, todos devem contribuir para que haja saúde, educação, entre outros serviços, fornecidos pelo Estado de maneira gratuita.

No caso do imposto, ocorrendo o fato gerador e o contribuinte deixando de pagar tal tributo, o Estado é dotado de prerrogativas e meios legais para que possa exercer a cobrança. Porém, no caso do IPVA, o Estado excede tal prerrogativa, através do poder de polícia, ele retira do contribuinte que está em débito o seu patrimônio, condicionando sua devolução ao pagamento do imposto, juntamente com outros encargos legais. 
O legislador também se excede ao condicionar a emissão da CRLV - documento de porte obrigatório para todo motorista para que possa atestar que seu veículo possui condições de trafegar em segurança ao pagamento do IPVA - imposto incidente sobre a propriedade do seu veículo.

Desta forma, conclui-se que o legislador comete um equívoco e uma possível inconstitucionalidade ao instituir no artigo $131, \S 2^{\circ}$ do CTB, a condição de quitação do IPVA para que possa receber seu certificado de registro e licencimaneto de veículos - CRLV, bem como o Estado excede, através do poder de polícia ao apreender o veículo que não tenha pagado o IPVA, tornando a apreensão uma prática ilegal, e condicionando a retirada do veículo ao pagamento do imposto.

À vista disso, busca-se que o Estado utilize-se dos meios legais já conferidos, para que proceda a cobrança do IPVA, como também, obedeça às regras legais e aos princípios constitucionais auferidos a todos os cidadãos de um Estado democrático de direito.

\section{REFERÊNCIAS BIBLIOGRÁFICAS}

AMARO, Luciano. Direito tributário brasileiro. 14 ed. São Paulo: Saraiva, 2008.

BALEEIRO, Aliomar. Direito tributário brasileiro. Atualização de Misabel Abreu Machado Derzi. 12 ed. Rio de Janeiro: Forense, 2013.

BRASIL. (Constituição 1988). Constituição da República Federativa do Brasil de 1988. Disponível em <http://www.planalto.gov.br/ccivil_03/constituicao/constituicaoco mpilado.htm>. Acesso em 06 fev 2017.

. Lei $\mathrm{n}^{\circ}$ 9.503, de 23 de setembro de 1997. Institui o Código de Trânsito Brasileiro. Brasília 1997. Disponível em <http://www.planalto.gov.br/ccivil_03/leis/L9503.htm>. Acesso em 07 fev 2017.

. Lei $\mathrm{n}^{\circ} 5.172$, de 25 de Outubro de 1966. Dispõe sobre o sistema tributário nacional e institui normas gerais de direito tributário aplicáveis à União, Estados e Municípios. Disponível em 
www.planalto.gov.br/ccivil_03/leis/L5172Compilado.htm> Acesso em 28 jan 2017.

CARVALHO, Paulo de Barros. Curso de direito tributário. 23. ed. São Paulo: Saraiva, 2011.

CARVAlHO FILHO, José dos Santos. Manual de direito administrativo. 25 ed. São Paulo: Atlas, 2012.

COÊLHO, Sacha Calmon Navarro. Comentários à Constituição de 1988. 7 ed. Rio de Janeiro: Forense, 1998.

DI PIETRO, Maria Sylvia Zanella. Direito administrativo. 26 ed. São Paulo: Atlas, 2012.

ELIAS ROSA, Márcio Fernando. Direito Administrativo Parte I Sinopses Jurídicas. Vol. 19. 12 Ed. 2011.

FRANÇA, Reginaldo de. Fiscalização tributária: prerrogativas e limites. 2 ed. Curitiba: Juruá, 2012.

GASPARINI, Diógenes. Direito administrativo. 16 ed. São Paulo: Saraiva, 2011.

GOMES, Fábio Bellote. Elementos de direito administrativo. 2 ed. São Paulo: Saraiva, 2012.

HARADA, Kiyoshi. Direito financeiro e tributário. 19 ed. São Paulo: Atlas, 2010.

$\mathrm{KOCH}$, Deonísio. Processo administrativo tributário e lançamento. Florianópolis: Editores, 2012.

MAMEDE, Gladston. IPVA: imposto sobre a propriedade de veículos automotores. São Paulo: Revista dos Tribunais, 2002.

MARTINS, Sérgio Pinto. Manual de direito tributário. 11. ed. São Paulo: Atlas, 2012.

MEDAUAR, Odete. Direito administrativo moderno. 18 ed. rev. e atual. São Paulo: Revista dos Tribunais, 2014.

MEIRELLES, Hely Lopes. Direito administrativo brasileiro. 37 ed. São Paulo: Malheiros Editores, 2011.

MELLO, Celso Antônio Bandeira de. Curso de direito administrativo. 26 ed. São Paulo: Malheiros, 2009.

MESSA, Ana Flávia. Limites principiológicos da fiscalização tributária. Revista Tributária e de Finanças Públicas. São Paulo, ano 16. n. 82 set-out 2008, Revista dos Tribunais.

NABAIS, José Casalta. O dever fundamental de pagar impostos. Contributo para a compreensão constitucional do estado fiscal contemporâneo. Coimbra: Almedina, 1998. 
SABBAG, Eduardo de Moraes. Manual de direito tributário. 6 ed. São Paulo: Saraiva, 2014.

SILVA, Paulo Roberto Coimbra. IPVA: Imposto sobre a propriedade de veículos automotores. São Paulo: Quartier Latin, 2011. 